Date of this draft: April 10, 2009

\title{
THE ROLE OF BANKS IN THE SUBPRIME FINANCIAL CRISIS
}

\author{
Michele Fratianni* and Francesco Marchionne**
}

\begin{abstract}
$\underline{\text { Abstract }}$
The ultimate point of origin of the great financial crisis of 2007-2009 can be traced back to an extremely indebted US economy. The collapse of the real estate market in 2006 was the close point of origin of the crisis. The failure rates of subprime mortgages were the first symptom of a credit boom tuned to bust and of a real estate shock. But large default rates on subprime mortgages cannot account for the severity of the crisis. Rather, low-quality mortgages acted as an accelerant to the fire that spread through the entire financial system. The latter had become fragile as a result of several factors that are unique to this crisis: the transfer of assets from the balance sheets of banks to the markets, the creation of complex and opaque assets, the failure of ratings agencies to properly assess the risk of such assets, and the application of fair value accounting. To these novel factors, one must add the now standard failure of regulators and supervisors in spotting and correcting the emerging weaknesses. Accounting data fail to reveal the full extent of the financial maelstrom. Ironically, according to these data, US banks appear to be still adequately capitalized. Yet, bank undercapitalization is the biggest stumbling block to a resolution of the financial crisis.
\end{abstract}

JEL Classification: G01, G21, N20

Keywords: accounting, banks, credit, crisis, fair values, risk aversion, undercapitalization.

* Corresponding author, Indiana University, Kelley School of Business, Bloomington, Indiana (USA) and Università Politecnica delle Marche, Ancona (Italy), email: fratiann@indiana.edu. ** Università Politecnica delle Marche, Ancona (Italy), email: f.marchionne@univpm.it. We thank Matteo Cassiani for providing bank market data, Greg Udell for insights on US bank accounting data, and Charles Trczinka for sharing with us his price-to-earnings data on US stocks. 


\section{INTRODUCTION}

The most severe financial crisis we are living through since that of the Great Depression has many of the features of a credit-boom-and-bust (CBB for short) crisis. The time line of a CBB crisis goes as follows; see Fisher (1933), Minsky (1977), and Kindleberger (1978). The point of origin of the crisis is a shock (for example, a real estate boom) that alters the profit outlook in the economy. Bank credit, or credit in general, feeds the boom. Households accumulate debt relative to net worth; firms increase leverage to finance new projects based on optimistic assessments of future profits. For Fisher (1933, p. 341), “...over-investment and over-speculation are often important; but they would have far less serious results were they not conducted with borrowed money.” Optimism about the future drives the process of capital and debt accumulation. Monetary expansion comes with or promotes the expansion of bank credit; see Kindleberger (1978, ch. 4). Surging asset prices feed optimism about future price rises. We can characterize this phase as one of low-risk aversion. Investors are more concerned about what other investors are doing than making their own independent assessment of the situation, that is, they herd.

Then, a shock breaks the boom. The list of possible negative events includes a tightening of monetary policy, a real estate or equity crash, or the failure of a large financial institution. Whatever the disturbance, it deteriorates critically what Minsky (1977) calls the "margin of safety," the excess of assets over liabilities or the excess of positive cash flows over negative cash flows. Now, the future appears dark and anticipated profits decline. Risk aversion surges among investors. Asset prices implode as speculators unload risky assets. Again, referring to Minsky (1982, p. 42), “[a] recursive process is readily triggered in which a financial market failure leads to a fall in investment which leads to a fall in profits which leads to financial failures, further declines in investment, profits, additional failure, etc.” A rush for liquidity and deleveraging follows. With debt liquidation, inflation falls below expectations. Disinflation forces a rise in the real value of debt and debtors suffer a decline in net 
worth (Fisher 1933, pp. 342-3). Even without disinflation, declining asset prices lower the value of collateral and force borrowers to put up more security for a given nominal value of debt.

Our paper argues that the current crisis has many features of the time line implied by the CBB hypothesis. However, as it is true for other crises, there are some features that are unique to this crisis, such as the transfer of assets from the balance sheets of banks to the markets, the creation of complex and opaque assets, the failure of ratings agencies to properly assess the risk of such assets, and the application of fair value accounting. ${ }^{1}$ These novel aspects have weakened the resilience of the financial system and transformed a crisis of a relatively small segment of the market in the United States into a deep and global one. The attempt of banks to unload risk off balance sheets fired back. The complex products created by the "originate and distribute" banking model ultimately instilled a deep sense of distrust among investors. When those complex products were brought back into the balance sheets, banks booked capital losses, as a result of fair value accounting, and declared write-downs. Banks found themselves undercapitalized and sold assets to reduce leverage; they thus set in motion a vicious circle of asset liquidation and price declines across a vast range of assets. The public's high degree of risk aversion demanded that banks held more capital per dollar of assets, while asset markdowns and write-downs were actually destroying capital. In brief, banks became heavily undercapitalized, reflecting bloated balance sheets, poor quality of the assets, and a distrustful public. Undercapitalization explains why the crisis persists and governments continue to inject vast amounts of public funds into banks. The crisis is not likely to end until balance sheets will have expurgated socalled toxic assets. Banks will not resume lending until balance sheets will be cleansed and undercapitalization has been overcome.

\footnotetext{
${ }^{1}$ In a series of publications, Paolo Savona and various co-authors have underscored how the introduction of new financial products, but especially derivatives, has altered the nature of money; see, for example, Savona and Maccario (1999). This aspect of the crisis is a theme in its own right but is beyond the scope of our paper.
} 
The focus of our paper is on banks, specifically what role they have had in sparking the crisis, what actions they have taken in reducing leverage, and how security markets have penalized bank equity. Our account of the behavior of banks falls within the framework of the CBB hypothesis. By design, we ignore several important topics, among which the impact of the crisis on the real economy and on the conduct of monetary policy. Nor do we compare this crisis to others before; on this theme, see Fratianni (2008).

The paper is organized as follows. Section II argues that the ultimate point of origin of the crisis must be found in a highly indebted US economy. Section III looks at subprime mortgage loans, the close point of origin of the crisis, and the political context that encouraged them. Sections IV examines how the fire spread from a relatively small segment of the real estate mortgage market to security markets worldwide. Section V presents descriptive statistics, drawn from banks’ financial statements and security markets, on the breadth and depth of the financial crisis; the essential point there is that accounting data, not surprisingly, are less informative than market data. Summary and conclusions are presented in Section VI.

\section{AN INDEBTED US ECONOMY}

Signs that the US economy was on a classic pattern of a big credit boom have been present for quite some time. Figure 1 shows the growth rate of US households' debt over the period 1977-2008. To the growth of total debt we have superimposed the growth of mortgages, which displays a very tight positive correlation with the growth of household debt. The previous credit boom started in the early 1980s, peaked in the middle of the decade and was followed by a deceleration that lasted several years. The current credit book started in the mid 1990s, peaked between the first and second quarter of 2006, and was followed by a credit bust. The difference between the two cycles is due to the 
evolution of home prices. Figure 2 displays the appreciation of US residential homes and its relationship to the cost of mortgage borrowing. Home price appreciation is measured by the annual percentage change of the S\&P/Case-Shiller Composite-20 US home price index and the cost of mortgage borrowing by the interest rate on 30-year conventional mortgages. Home price appreciation moved from an average of 10 percent from 2001 to 2003 to $15-17$ percent in 2004-2005. Deceleration in price appreciation took place in 2006; by the end of that year, prices were virtually flat. Actual price declines started in early 2007, and by year-end they were falling at an annual rate of 9 percent. At the end of 2008, prices were declining close to 20 percent. Looking at the spread between home price appreciation and cost of borrowing, the break-even point occurred in August of 2006. At the start of 2007, the spread was in the order of -600 basis points; in June of 2007, it had reached -1000 basis points, and at the end of 2008 -2400 basis points. ${ }^{2}$ The main inference from these data is that the credit bust manifested itself when the real estate price boom had already come to an end.

\section{[Insert Figures 1 and 2, here]}

Another way to characterize the indebted economy is to relate debt levels to GDP. Figures 3 depicts the evolution of the debt-to-GDP ratios of the US financial, household, and remaining domestic sectors. A sharp and continuous upward trend is manifest in the three sectors, but in particular in the financial and household sectors. From the start of the $21^{\text {st }}$ century to 2006, the year preceding the crisis, the last two ratios grew by approximately 40 percent. Finally, evidence of an indebted economy comes from the basic identity relating net capital flows to the difference between national saving and national investment. Table 1 shows that in the period 2001-2006, the United States had net foreign borrowings of $\$ 3,455$ billion, driven by a large and persistent excess of

\footnotetext{
${ }^{2}$ The relevant spread, of course, is between future home price appreciation and the current cost of borrowing. We have assumed, implicitly, that past home price changes are the best estimate of future ones.
} 
domestic absorption -the sum of domestic consumption, gross investment, and government spending- over domestic production (BIS 2008, pp. 28-29). For any other country, the required adjustment would have entailed a contraction of domestic absorption relative to output, a sharp depreciation of the home currency in the exchange markets, and a shift from non-traded goods to traded goods production. But the key role of the dollar in the international monetary system has softened the external constraint of the United States and given it a unique capacity to borrow massive amounts of foreign capital at interest rates that do not imbed a significant degree of credit risk (Alessandrini and Fratianni 2009 forthcoming). ${ }^{3}$ In sum, the U.S. economy, as a whole, was highly leveraged by the time the crisis erupted.

[Insert Figure 3 and Table 1, here]

\section{SUBPRIME MORTGAGES}

Subprime mortgages were an innovation of the 1990s, spurred by the demise of usury laws, financial deregulation, and the Community Reinvestment Act of 1977 that gave incentives to lenders to extend loans to individuals with low income and limited or outright poor credit histories (Gramlich 2007). The Act was accompanied by "regulatory relief." Just to mention an example of the latter, banks had to demonstrate that they were meeting the objectives of the Act by making a certain number of loans to people with low or moderate incomes. Prudence and credit evaluations were replaced by more flexible procedures that justified lending to the targeted clientele (Wallison 2009). Furthermore, the two

\footnotetext{
${ }^{3}$ Bernanke (2005) gives a 'benign' interpretation of the large U.S. capital inflows, based on forces external to the United States, namely from a rightward shift of the saving function in fast-growing Asia and oil-producing economies unmatched by a comparable shift in their investment function. The resulting ex-ante gap between saving and investment has resulted in current-account surpluses and in falling real rates of interest. The developed world, but primarily the United States, has "had" to absorb the capital inflows generated by Asia and oil-producing countries.
} 
government-sponsored agencies, Fannie Mae and Freddie Mac, were entrusted with the mission of expanding the market for cheaper housing. These two government-sponsored agencies

“... used their affordable housing mission to avoid additional regulation by Congress, especially restrictions on the accumulation of mortgage portfolios (today totaling approximately \$1.6 trillion) that accounted for most of their profits. The GSEs [government-sponsored agencies] argued that if Congress constrained the size of their mortgage portfolios, they could not afford to adequately subsidize affordable housing. By 1997, Fannie was offering a 97 percent loan-to-value mortgage. By 2001, it was offering mortgages with no down payment at all. By 2007, Fannie and Freddie were required to show that 55 percent of their mortgage purchases were LMI [low-to-moderate income] loans, and, within that goal, 38 percent of all purchases were to come from underserved areas (usually inner cities) and 25 percent were to be loans to low-income and very lowincome borrowers. Meeting these goals almost certainly required Fannie and Freddie to purchase loans with low down payments and other deficiencies that would mark them as subprime or Alt-A", (Wallison 2009, p. 3).

In 1994, subprime loans were five percent of total mortgage origination; by 2005, it had risen to 20 percent. Over the period 1994-2005, this market grew at an average annual growth rate of 26 percent and expanded home ownership by an estimated 12 million units. A great deal of subprime origination was made by independent, federally unregulated, lenders who applied adjustable interest rates and often so-called teaser rates. Practices, such as excluding taxes and interest rates from escrow accounts and prepayment penalties, were widespread. All of this was driven by the property boom.

The credit boom and the politics of lending led to a progressive deterioration of credit standards from 2001 to 2007 (Demyanyk and van Hembert forthcoming). Simple descriptive statistics show a negative correlation between changes in the quantity of subprime loans and changes in denial rates on subprime loan applications, and a positive correlation between changes in the quantity of subprime loans and changes in the ratio of loan size to borrower's income (Dell'Ariccia et al. 2008, Figure 4). Declining lending standards were correlated with rapid home price appreciation, evidence that is consistent with the hypothesis that the housing boom was driving both the expansion of credit and

\footnotetext{
${ }^{4}$ Alt-A stands for Alternative A-paper, a mortgage that is riskier than a prime mortgage but less risky than a subprime mortgage.
} 
declining lending standards. Finally, an expansive monetary policy was providing added impetus to a loosening of the standards (Dell'Ariccia et al. 2008, especially p. 18). The link between CBB and monetary policy is hardly surprising; for a review of the evidence see Berger and Udell (2004).

\section{SPREADING THE FIRE}

Actual and projected bank write-downs on low-quality mortgages represent approximately 25 percent of estimated losses on prime, commercial real estate, and consumer and corporate loans; and 9 percent of the estimated mark-to-market losses on asset-backed securities (ABS), collateralized debt obligations (CDO), prime mortgage-backed securities (MBS), collateralized MBS (CMBS), collateralized loan obligations (CLO), and corporate debt; see IMF (2008a, Table 1.1). ${ }^{5}$ Large default rates on subprime mortgages cannot explain the depth of this crisis. Subprime mortgages were the accelerant to the fire after the real estate bust short circuited in the financial house. The fire spread quickly and globally because this house was built with combustible material, such as structured finance and inadequate supervision; a sudden rush for liquidity and fast deleveraging exacerbated by the practice of fair value accounting kept the fire running.

\section{$\underline{\text { Structured finance }}$}

We use the term structured finance to encompass a series of banking and financial innovations aimed at transferring credit risk from individual financial institutions to the market as a whole. The innovation that best characterizes this crisis is the "originate and distribute" bank model, in which banks originate loans or purchase loans from specialized brokers to either sell them in the financial markets or transfer them to a sponsored structured investment vehicle (SIV). The SIV, in turn,

\footnotetext{
${ }^{5}$ The estimate of total losses, as of October 2008, is placed at $\$ 1,405$ billion.
} 
packages the loans into residential MBS, commercial MBS, CDOs, and CLOs; all of these financial acronyms may receive a credit risk score by ratings agencies. In addition to the capital provided by the sponsoring institution, the SIV obtains funding by borrowing short term in the commercial paper market and from banks; in other words, they perform a classic maturity transformation. Should the SIV be unable to refinance itself, it can count on a contingency support from its sponsoring bank. Commercial paper conduit is another off-balance sheet entity that is the product of the new age of finance; it obtains the entire funding from the commercial paper market and invests in trade receivables and other non-tradable assets such as credit cards, consumer loans, automobile loans, and real estate loans. In 2007, SIVs and commercial paper conduits held assets for $\$ 1,800$ billion (IMF 2008a, Box 2.5).

Two serious problems arise with the practice of structured finance. The first regards the incentive of the originator to screen debtors when the loans are destined to be placed off balance sheet. Reputational considerations would suggest that the originator would not want to compromise its standards. However, the fact that regulators and accounting standards required little disclosure about unconsolidated off-balance sheet entities made these entities opaque to investors and lowered the cost of reputational loss to the sponsoring institution. To complicate matters, the ratings agencies were not up to the task of properly evaluating the new complex products. Errors in judgment were as glaring as assigning the same letter grade to a CDO and a corporate bond with sharply different default rates. ${ }^{6}$ The second concerns the contingency that the off-balance sheet entities may be reabsorbed by the sponsoring institution. Balance-sheet absorption can occur either because the sponsoring institution covers more than half of the trading losses of the sponsored SIV or because the sponsoring institution wants to prevent a downgrade of the SIV's credit risk (IMF 2008a, Box 2.6).

${ }^{6}$ Calomiris (2007, p. 19) quotes from the Bloomberg Market of July, 2007 that CDOs rated Baa by Moody suffered five-year default rates of 24 percent, whereas corporate bonds with the same rating had default rates of 2.2 percent. 
At that point, there is a reversal of the intended benefits of “originate and distribute;" namely, risk returns home and regulatory capital rises. The investor, having finally gained transparency in the transaction, may judge correctly that the sponsoring bank is overleveraged and demands for it a higher required return on capital; this translates into a spot drop in the share price of the consolidated bank.

\section{Rush for liquidity}

As we have noted, a credit bust typically occurs with a rush for liquidity and a sharp re-pricing of credit spreads. The liquidity crisis exploded in the interbank market in August of 2007. On August 8, 2007, the interbank rate in the euro zone spiked to 4.6 percent against a value of 4 percent of the policy rate. The following day, the European Central Bank (ECB) injected $€ 95$ billion of liquidity, accepting all requests for funding at the policy rate. The Fed did not implement any emergency steps, but put an unusually large \$24 billion into U.S. markets in scheduled open market operations. Other central banks either injected additional liquidity or issued statements of their willingness to do so. Additional injections of monetary base were made by the ECB in the next three working days for an amount approximately half of the Thursday's intervention. Yet, spreads of three-month interbank lending rates relative to either policy rates or yields on three-month Treasury bills remained exceptionally high. Take, for example, the so-called TED spread, the difference between the threemonth Libor interest rate and the three-month U.S. Treasury bill. Under ordinary times, TED values are contained within 20 to 30 basis points. At the peak of the Mexican crisis of 1994-95 and the South-East Asian financial crisis of 1997, TED rose to approximately 60 basis points. In the Gulf War and the crisis of Long Term Capital Management, TED peaked at approximately 120 basis points. During the entire subprime crisis, TED has moved to uncharted territory; see Bloomberg Web site (http://www.bloomberg.com/apps/quote?ticker=.TEDSP\%3AIND). From September 15 to 
October 14 of 2008 -13 months after the initial liquidity shock of August, 2007- TED averaged over 300 basis points and reached an all-time high of 464 points on October 10, 2008, the Friday that ended a historic week of panic selling in the equity markets. A similar story is told by the spread between uncollateralized interbank interest rates and overnight index swaps; see IMF (2008b, Figure 2.2).

The markets were gripped by fears of credit and liquidity risks, two risks distinguishable in theory but not in practice (IMF 2008b, pp. 78-81). The fact that the massive injections of monetary base by central banks -only at first with no lasting effects on either bank reserves or the monetary base (Borio and Nelson 2008, p. 39)- were ineffective in containing the spreads in the interbank market is consistent with the view that market participants were worried of large credit risks and adverse selection and that they could not separate liquidity from credit concerns.

Interest rate spreads are negatively correlated to CBB cycles. Before a crisis, credit risk spreads tend to be low; then they erupt with the onset of a crisis. This pattern happened with a vengeance in the current crisis. Spreads relative to yields on government bonds shot up for commercial paper and nontriple A rated corporate bonds in the United States, the Euro area, and Japan; see IMF (2008b, Figures 4 and 5, pp. 172-3). ${ }^{7}$ The switch in the public's degree of risk aversion was justified by the mounting difficulty of gathering reliable information on opaque clients in times of distress. Confronted with more uncertainty in assessing the true credit status of relatively opaque borrowers, creditors had no better method than applying higher interest rates to entire classes of borrowers.

\section{$\underline{\text { Fair value accounting }}$}

Both GAAP (Generally accepted accounting principles with jurisdiction over US companies) and IFRS (International financial reporting standards with jurisdiction over European companies) prescribe so-

${ }^{7}$ See Mishkin (1991) for historical evidence from the $19^{\text {th }}$ and $20^{\text {th }}$ century US panics. 
called fair valuation for financial assets with a holding period less than maturity. For US entities, debt and equity securities can be classified as either "held-to-maturity,” or “trading,” or "available-for-sale” (FAS \# 115). The first are reported at amortized cost; the second at fair value, with unrealized gains or losses included in earnings; and the third at fair value, with unrealized gains and losses excluded from earnings but included in shareholders' equity. Thus, unrealized gains or losses of trading securities and available-for-sale securities affect owners' capital. ${ }^{8}$ As an example, for 2008 Citigroup lists tradingaccount assets of $\$ 378$ billion and trading-account liabilities of $\$ 167$ billion, on which it reports unrealized losses of $\$ 20.5$ billion (Citigroup 2008, p. 117 and p. 119). ${ }^{9}$ Despite restrictions, management can elect to move assets from one category to another. Again using Citigroup as an example, in 2008 \$64.9 billion securities were moved out of the “trading-account assets” category, of which $\$ 60.3$ billion went into the "held-to-maturity” category and $\$ 4.6$ billion went into the "availablefor-sale investments” category (Citigroup 2008, pp. 86-87). According to US GAAP, fair values are determined according to a three- level hierarchy (FAS \# 157). At the top of the pyramid, there are liquid assets for which exist quoted prices for identical instruments in active markets; the rule prescribes the use of observed unadjusted prices. At a lower level, there are assets for which quoted prices exist only for similar instruments in active markets, or quoted prices exist for identical or similar instruments in markets that are not active. Here, the prescription is to use market observables to estimate values based on a specific valuation model (e.g., the Black-Scholes option model). At the lowest level of the pyramid, there are assets for which some or all of the inputs for valuing assets are unobservable. Here, the valuation model must rely not on publicly available information but on internal one. A particularly troublesome (contentious) issue is the use of market values when markets are illiquid: selling in such markets would constitute a forced liquidation or distress sale and market

\footnotetext{
${ }^{8}$ While not exactly the same, the IFRS has a similar prescription.

${ }^{9}$ These unrealized losses are recorded under "accumulated other comprehensive income (loss)," which is a component of "stockholders' equity" on the consolidated balance sheet.
} 
values would not represent fair values. ${ }^{10}$ However, one must be reasonably sure that the fair value established by the reporting unit were to reflect reliable assumptions about the future net cash flows associated with an asset; in other words, the only source of inefficiency must be due to markets suffering from illiquidity. In practice, it is extremely difficult to distinguish between illiquidity and credit risk.

In sum, fair value accounting has four important implications. The first is that unrealized gains and losses impact owners' capital. The second is that, like for any other accounting rule, fair valuation provides incentives to management to game the rules to boost earnings (or reduce losses) and management bonuses linked to earnings’ performance. Thus, during periods of rising asset prices, the incentives will be to move assets into the trading account categories, and conversely during declining asset prices. The third is that when markets become less liquid, valuation models based on internal information become more relevant than valuation models based on observables and the latter more relevant than the use of unadjusted quoted prices. In the presence of patently illiquid markets, an argument can be made that fair values should be based on reliable estimates of future net cash flows. Finally, the pro-cyclical bias of fair value accounting tends to magnify current financial trends and, consequently, exacerbates a financial crisis (Wallison 2008). Lower accounting asset values that impact on regulatory capital may trigger management to sell in illiquid markets.

\section{Deleveraging}

The big impact of the subprime occurred through the re-pricing of risk across a variety of assets, a

\footnotetext{
${ }^{10}$ On this point, the latest posting on the Web site of the Financial Accounting Standards Board says that "The notion of unobservable inputs is intended to allow for situations in which there is little, if any, market activity for the asset or liability at the measurement date. In those situations, the reporting entity need not undertake all possible efforts to obtain information about market participant assumptions. However, the reporting entity must not ignore information about market participant assumptions that is reasonably available without undue cost and effort”; see http://www.fasb.org/st/summary/stsum157.shtml
} 
scramble for liquidity and a shrinking of balance sheets. Spillovers across markets and a scramble for liquidity are the standard prediction of the CBB hypothesis. Fair value accounting and structured finance are the new elements that explain the intensity and speed of deleveraging we have been observing during the crisis. To see this point, consider the balance sheet identity A = D + E, where A $=$ value of assets marked to market, $\mathrm{D}=$ value of debt and $\mathrm{E}=$ value of equity. Under fair value accounting, an unrealized loss in residential MBS, held under trading account, triggers a decline in A and in $E$ with a consequent rise of the leverage ratio, $L=A / E=A /(A-D)$. A higher $L$ sends a bad signal to the market, which suspects that other assets in the books are in danger of being devalued. The public, furthermore, is aware that management has an incentive to reclassify assets out of the trading account category. Hence, the public becomes more risk averse and banks react by shrinking L. This can be done either by selling assets or by recapitalizing. Recapitalization was aggressively pursued in the first phase of the crisis: from the second half of 2007 through September 2008, global banks raised $\$ 430$ billion of fresh capital (IMF 2008b, p. 22). Then, recapitalization became increasingly difficult, and leverage had to be lowered by selling assets in illiquid markets. Thus, in the absence of fresh capital and without significant profits to retire debt in the short run, the deleveraging process necessarily implies distress sales and falling asset values (Adrian and Shin 2008, Figure 2.5). ${ }^{11}$

The shorter the horizon over which deleveraging must occur, the more dramatic is the implosion of asset prices. The rapidly rising risk aversion of the public, fed by bad news and the thick fog of asymmetric information, is pushing financial institutions to compress leverage quickly. Fair

\footnotetext{
${ }^{11}$ For the individual bank, $\mathrm{L}$ can be lowered by selling A without affecting its prices, but for the financial system as a whole it cannot. Note that the derivative of $\mathrm{L}$ with respect to $\mathrm{A}$ is negative only if $\mathrm{D}$ is fixed. If $\mathrm{D}$ has to adjust to satisfy a new target level of L, a sufficient amount of A must be sold to lower D; then, L and A are positively associated (Adrian and Shin 2008, Figure 2.5). As an example, consider a banking system with initial values of $A=200, D=190$ and $\mathrm{E}=10$; and that leverage needs to lowered from 20 to a new value of 10 . A possible new configuration might be $A=70, D=63$ and $E=7$. With nominal units of $A$ and $D$ fixed, the shrinking of the balance sheet must occur through a deflation of asset prices.
} 
value accounting aggravates the problem through its pro-cyclical bias. Lower accounting asset prices impact negatively on regulatory capital and may push bankers to engage in liquidation sales that further depress asset prices.

In the end, the required adjustment turned out to be too quick and ultimately government had to step in with rescue plans.

\section{WHAT BANKS' ACCOUNTING AND MARKET DATA TELL US ABOUT THE CRISIS}

In this section, we address two critical issues. The first is to examine whether banks' financial statements gave us any significant warning value about the impending crisis. The second is to compare the stock markets' reaction to the crisis to the information value of the financial statements and infer from this comparison to what extent the source of the problems was outside the banks' balance sheets.

Leverage is a critical indicator of the risk financial institutions are willing to undertake. Figure 4 displays the ratio of total assets to equity, a measure of leverage, for selected US investment banks and commercial banks for the months of June of 2007 and June and September of 2008. Based on this criterion, investment banks stand out for their propensity to undertake risk. Of the five large US investment banks, Lehman Brothers went bankrupt, Bear Stearns and Merrill Lynch were acquired by other banks, and Goldman Sachs and Morgan Stanley decided to accept leverage restrictions when they elected to become commercial bank holding companies and thus be subject to the Fed's regulation and supervision. ${ }^{12}$ High leverage is also a characteristic of many European banks. It is striking that 12 out of the selected 25 banks shown in Figure 5 have leverage ratios that are much higher than those of the US investment banks (in particular, higher than Lehman Brothers' leverage

\footnotetext{
${ }^{12}$ Lehman Brothers’ leverage ratio rose up to March of 2008 before declining.
} 
ratio before it filed for bankruptcy protection). ${ }^{13}$ There are significant differences among European banks, with British, French, German, and Swiss banks having, on average, much higher leverage ratios than Italian banks. German and English banks stand out for having raised their already high leverage up until June 2008. Among Italian banks, Unicredit is the closest to the model of the US investment banks, Deutsche Bank and UBS. In sum, the appetite for risk appeared to be high on both sides of the Atlantic and more in the North of Western Europe than in the South.

[Insert Figures 4 and 5, here]

A second way to investigate whether banks have assumed more risk during the credit boom is to look at the composition of bank loans. The large database of the FDIC on US banks permits us to identify categories of loans that historically have been high in risk. As a broad measure of bank credit risk, we take the ratio of three high-risk loan categories to total assets. The three high-risk categories are real estate loans, credit card loans, and certificates of participation in pools of residential mortgages. Figure 6 plots this credit risk proxy, on a quarterly frequency, from 2002 to 2008 for small, medium, and large banks. Small banks are defined as having total assets less than $\$ 100$ million; medium banks between $\$ 100$ million and $\$ 1$ billion; and large banks with more than $\$ 1$ billion. We also display the value of the credit risk proxy for the US banking system as a whole.

We consider first large banks, the alleged culprit of the crisis: the bank credit risk proxy rises from 35.7 percent at the end of 2002 to 42.6 percent at the end of 2006 and then declines throughout 2007 and 2008, a pattern that is consistent with the evolution of the credit boom and subsequent bust. Small and intermediate banks are the surprise. Their bank credit risk proxy rises continuously over the six-year period: by 7 percentage points for small banks and almost 9 percentage points for intermediate banks. While large banks make the greatest contribution to the total, small and intermediate banks proportionately have at least done no less than large banks. We can refine the

\footnotetext{
${ }^{13}$ Note, however, that accounting standards are not strictly comparable across different areas of the world.
} 
propensity to risk taking by focusing on construction and development loans, a particularly risky subset of real estate loans. ${ }^{14}$ Figure 7 displays the value of these loans as a percent of net loans and leases at the end of 2002 and 2006; call it a narrow proxy of bank credit risk. This rises sharply across the three class sizes of US banks, but especially for the intermediate size. At the end of 2002, the narrow proxy of credit risk was 7.3 percent for large banks against 5.9 percent for small banks and 8.8 percent for intermediate banks; by the end of 2006, the narrow proxy had doubled for intermediate banks, while it had risen by 54 percent for small banks and 66 percent for large banks. On this metric alone, the accounting data suggest that the appetite for risk was no less for small and intermediate banks than for large banks.

\section{[Insert Figures 6 and 7, here]}

Altogether different is the story for securitization. Large US banks are dominant in this area; see Figure 8. The ratio value of securitization activities -covering real estate loans, credit cards receivables, automobile loans, other consumer loans, and commercial and industrial loans- of total bank assets for large US banks starts at 14.5 percent at the end of 2002, reaches a peak of 18.6 percent in the first quarter of 2007, and then flattens out. At the end of 2008, securitization activities at large US banks were booked for $\$ 1,907$ billion. In contrast, the securitization-asset ratio for intermediate bank was below one percent and has trended downward over the six-year period. Small US banks are not materially involved in securitization. A similar pattern holds for the ratio of the value of derivatives - defined as the sum of notional value of credit derivatives, interest rate contracts, foreign exchange rate contracts, and notional value of derivatives on equities and other commoditiesas a percent to total bank assets across bank sizes; see Figure 9. The magnitudes involved here, however, are much higher. At the end of 2008, derivatives at large US banks were booked for

\footnotetext{
${ }^{14}$ We owe this insight to Gregory Udell.
} 
\$201,061 billion, 14 times US GDP in current dollars. ${ }^{15}$ Small and intermediate banks are not materially engaged in derivatives. In sum, complex finance is done predominantly by large banks. Given the large sums involved and the off-balance sheet nature of securitization and derivatives, formal financial reporting is bound to deeply understate the true impact of a financial crisis on banks’ performance both in market upswings and downswings. Thus, to have a more complete appreciation of the extent of the current financial maelstrom, we need to turn to market data.

For this purpose, we collected equity prices for a sample of banks from three areas of the world: the United States, Western Europe, and the Pacific region. The actual list, shown in the Appendix, includes 42 US banks, 49 banks from 14 different Western European countries, and 26 banks from three different Pacific region countries. ${ }^{16}$ The listed banks tend to be large and thus capable of engaging in complex structured finance. We provide three sets of descriptive statistics. The first, displayed in Figure 10, are market capitalization values for the three bank-area aggregates. The second, displayed in Figure 11, are holding-period dollar rates of return, again for the three bankarea aggregates. The third, shown in Table 2, provides rates of return, both in local currency and in dollars, for banks aggregated at the country level. The sample period goes from July 31, 2007, our benchmark of pre-crisis date, to March 17, 2009, our last observation. To simplify the presentation, we have taken a few benchmark dates in computing market capitalization and rates of return: the end of 2007, the end of the first and second quarter of 2008, September 14, 2008, the end of 2008, the end of February 2009 and the final observation of March 17, 2009. Some dates, such as quarter ends, are arbitrary but serve the purpose of underscoring the time evolution of the crisis. The $14^{\text {th }}$ of September

\footnotetext{
${ }^{15}$ Note that we are dealing with notional values and not with estimates of banks' risk exposure. US GDP in 2008 was $\$ 14,264$ billion. Total assets of US large banks at the end of 2008 were $\$ 11,054$ billion or, approximately, 77 percent of US GDP.

${ }^{16}$ Only the largest listed banks are included. For Ireland, Norway, and Switzerland, we have only one bank each (see Appendix). Moreover, we exclude CME Group Inc., Discover Financial Services, and Invesco Ltd from the group of US banks because they did not make the list at the end of July 2007.
} 
of 2008 is significant because is the day before Lehman Brothers filed for Chapter 11 bankruptcy protection; this event is widely believed to have represented a watershed in the crisis. The end of February, 2009 was selected as the approximate bottom of bank stock declines. To save space, Table 2 considers only three periods: the first phase of the crisis from July 31, 2007 to pre-Lehman's failure, the expanded phase of the crisis until the end of February of 2009, and a further expanded phase including a modest recovery that goes up to our last observation of March 17, 2009.

[Insert Figures 8-11 and Table 2, here]

Over the period July 2007-February 2009 period, the crisis has destroyed \$3,000 billion of market values in our sample of banks. European banks were hit the hardest with a 75 percent decline, the Pacific banks were hit the mildest with a 48 percent decline, and US banks fared in the middle with a 68 percent decline; see Figure 10. The decline, furthermore, was at least twice as large after September 14, 2009 than in the previous sub-period. This is quite apparent from the holding-period rates of return shown in Figure 11, and corroborates the view that the Lehman failure was perceived by the market as a critical event.

Table 2 compares rates of return at the national level, using both local-currency and dollar returns. Dollar returns are the sum of local-currency returns, the rate of dollar depreciation (or appreciation if negative) and the interaction between these two terms. The dollar depreciated relative to most currencies in the pre-Lehman period and appreciated in the post-Lehman period. Take bank stocks of the euro area. In the pre-Lehman period, rates of return in the euro area average -59 percent, over a range comprised between -42 percent for Austria and -92 percent for Portugal. Banks from France, Germany, Ireland and Portugal do worse than banks from Austria, Greece, Italy, and Spain. In the post-Lehman period, the euro average rate of return falls by an astounding -196 percent, over a range comprised between -88 percent for Spain and -391 percent for Ireland. Austrian, Belgian, German and Irish banks do much worse than French and Southern European banks. As we have 
already remarked in connection with dollar valuation, European bank stocks suffer the most, Pacific region bank stocks the least, and US bank stocks are in the middle. For most countries, but not for the United Kingdom, the differences between local-currency returns and dollar returns are of a small order of magnitude.

This massive destruction of market value can be attributed only in part to deteriorating fundamentals. As predicted by the CBB hypothesis, the crisis has made investors much more risk averse. To illustrate the extent of this shift in risk aversion, Figure 12 plots the distribution of price-toearnings ratios computed over 4,000 US equities for the year 2007 and 2008 (Trzcinka 2009). ${ }^{17}$ The 2008 distribution shifts sharply to the left of the 2007 distribution: the mean falls from 40.8 to 18.9 , the $10^{\text {th }}$ percentile from 10.4 to 3 , the $90^{\text {th }}$ percentile from 62 to 29.5 . Across a very broad range of US equities, investors were valuing a unit of 2008 earnings with a price multiple that was less than one half the price multiple accorded to 2007 earnings. In sum, rising risk aversion has magnified the effect of deteriorating fundamentals on bank stocks.

[Insert Figure 12, here]

\section{SUMMARY AND CONCLUSIONS}

We have argued that the ultimate point of origin of the great financial crisis of 2007-2009 was a credit boom that manifested itself in an extremely indebted US economy and in a high appetite for risk by investors. The collapse of the real estate market in 2006 was the close point of origin of the crisis. The failure rates of subprime mortgages were the first symptom of a credit boom tuned to bust and of a real estate shock. But large default rates on subprime mortgages cannot account for the severity of the crisis. Rather, low-quality mortgages acted as an accelerant to the fire that spread

\footnotetext{
${ }^{17}$ There are 4,363 firms in the 2007 sample and 4,010 in the 2008 sample.
} 
through the entire financial system. The latter had become fragile as a result of several factors that are unique to this crisis: the transfer of assets from the balance sheets of banks to the markets, the creation of complex and opaque assets, the failure of ratings agencies to properly assess the risk of such assets, and the application of fair value accounting. To these novel factors, one must add the more standard failure of regulators and supervisors in spotting and correcting the emerging weaknesses.

The banks' strategy of unloading risk off balance sheets fired back when investors finally became aware of the complexity underlying various asset backed securities; these investors reacted with a sharp increase in risk aversion. As these securities were brought back into the balance sheets, banks had to declare writedowns or book capital losses in accordance with the principles of fair value accounting. Falling capital values fueled additional anxiety in investors who were scared by bloated balance sheets and wanted instead less debt and more capital. Banks reacted by selling assets to reduce leverage, setting in motion a vicious circle of asset liquidation and price declines across a vast range of assets. Financial integration made possible for the crisis to spread virtually worldwide.

We examined accounting data to see whether they could offer any significant warning value about the impending crisis. We used four different metrics of risk taking: leverage, risk quality of bank loans, securitization, and derivatives. Leverage for US investment banks was much higher than for US commercial banks. Not surprisingly, of the five US large investment banks, only Goldman Sachs and Morgan Stanley have survived and both have changed business models since the start of the crisis. But leverage was also very high for some British, French and German universal banks. The point is that appetite for risk was high on both sides of the Atlantic. Risk quality of US loans, based on our credit risk proxy, deteriorated throughout the credit boom. While large banks contributed the most in an absolute sense, small and medium-size banks did just as well (or badly) in a proportionate sense. Large 
US banks instead were practically alone in engaging in large amounts of securitization and derivatives. These are the areas where the risks are likely to be deepest and yet least transparent.

Accounting data have severe limitations in revealing the full extent of this financial maelstrom. To illustrate, according to reported accounting data, the US banking system does not yet appear severely undercapitalized: at the end of 2008, the ratio of Tier 1 or core capital to risk-weighted assets was 17.4 percent for small banks, 12.3 percent for intermediate banks, and 9.4 percent for large banks. These ratios are way above the benchmark of 4 percent. Yet, it is widely acknowledged that banks are severely undercapitalized. Undercapitalization is the biggest stumbling block to a resolution of the financial crisis. In the span of 19 months, from July 2007 to February 2009, a selected sample of large US, Western European, and Pacific region banks lost \$3,000 billion of capitalization. European banks were hit the hardest; US banks were next. The bulk of the losses occurred after the failure of Lehman Brothers. This massive destruction of market value can be attributed only in part to deteriorating fundamentals. The financial crisis, not surprisingly, has made investors much more risk averse. Based on US equities, investors were valuing, on average, a unit of 2008 earnings with a price multiple that was less than half the price multiple accorded to 2007 earnings. Rising risk aversion and deteriorating fundamentals have reinforced each other in a brutal manner.

Banks' undercapitalization explains why the crisis persists and why governments continue to inject vast sums of public funds into banks. The crisis is not likely to end until balance sheets will have expurgated so-called toxic assets. Banks will not resume lending until balance sheets will have been cleansed and undercapitalization has been overcome. The greatest challenge may well be for politicians to convince an enraged public of the necessity of either further injections of funds into the banking systems or to undertake outright nationalizations. In the 1990s, Japan paid very dearly, with a so-called lost decade, for delaying the recapitalization of the banking system. The financial crisis in Japan started in 1991 and was induced by a real estate boom pierced by a tightening of monetary 
policy. The crisis was most severe from the middle of 1994 to 1996; there was a reoccurrence in 1997. Legislation to use public funds to recapitalize the banks was passed only in February of 1998 (Nakaso 2001, p. 11). Public’s hostility to use taxpayers’ funds was the main reason for the costly delay.

With the unwinding of the crisis, there will be a great flurry of proposals aimed at closing various regulatory loopholes that have spurred banks to take excessive risk taking. While this paper has purposefully avoided the topic of regulation and supervision, we like to point out that regulatory failure does not emerge in a vacuum (Fratianni 2008). If serious reforms have to be undertaken, the relationship between the legislator-principal and the regulator-agent must be at the top of the agenda. Consider the case of Fannie Mae and Freddie Mac. The U.S. Congress first privatized the de-facto duopolists in the secondary market for mortgage securities and then gave them a host of privileges, including an exemption from state tax liabilities, a mild regulatory and supervision umbrella, and a $\$ 2.25$ billion line of credit at the U.S. Treasury that allowed Fannie and Freddie to borrow with almost the credit status of the U.S. government. According to James Leach (2008), the former chairman of the House Banking and Financial Services Committee and thus a person who experienced directly the lobbying power of Fannie and Freddie, “[t]he legislated perks granted Fannie Mae and Freddie Mac are of a multi-billion dollar yearly magnitude and the regulatory advantages they enjoy magnify the capacity of each to grow. It is no accident that no commercial companies in the past generation have had as muscular a lobbying operation on Capitol Hill.” Regulators and the Fed have been subservient to the political will and their behavior has reinforced the historical record that the costs of resolving financial crises have been aggrandized by weak principal-agent relationships.

Regulators, like central banks, would perform better if they were given clear and nonconflicting objectives, made independent of the executive branch of government, and rendered accountable to the principal. Such independence could be made formal by a legislative act that would spell out the objectives of regulation and, at the same time, make the regulators accountable through 
periodic reporting to the Congress or the Parliament, as it is the currently the case for some central banks. 


\section{References}

Adrian, Tobias and Hyun Song Shin (2008). Liquidity and leverage. Federal Reserve Bank of New York; http://www.newyorkfed.org/research/staff_reports/sr328.html

Alessandrini, Pietro and Michele Fratianni (2009 forthcoming). Resurrecting Keynes to stabilize the international monetary system, Open Economies Review.

Bank for International Settlements (2008). $78^{\text {th }}$ annual report. Basle.

Berger, Allen and Gregory Udell (2004). The institutional memory hypothesis and the procyclicality of bank lending behavior, Journal of Financial Intermediation 12:458-495

Bernanke, Ben S. (2005). The global saving glut and the U.S. current account deficit, speech delivered for the Sandridge Lecture at the Virginia Association of Economists, Richmond, March 10; www.federalreserve.gov/boarddocs/speeches/2005/200503102/default.htm.

Board of Governores of the Federal Reserve System. Flow of funds accounts of the United States; http://www.federalreserve.gov/releases/z1/

Calomiris, Charles W. (2007). Not (yet) a ‘Minsky’ moment. Unpublished paper (October 5).

Citigroup (2008). Annual report on form 10-k; http://www.citigroup.com/citi/fin/sec.htm

Dell'Ariccia, Giovanni, Denis Egan and Luc Laeven (2008). Credit booms and lending standards: Evidence from the subprime mortgage market, International Monetary Fund, Working Paper WP/08/106.

Demyanyk, Yulya and Otto van Hemert (forthcoming). Understanding the subprime mortgage crisis, Review of Financial Studies.

Federal Deposit Insurance Corporation, Statistics on banking; http://www2.fdic.gov/SDI/SOB/

Fisher, Irving (1933) The debt deflation theory of great depressions, Econometrica Vol. 1; 337-57.

Fratianni, Michele (2008 forthcoming). Financial crises, safety nets and regulation, Rivista Italiana degli Economisti.

Gramlich, Edward M. (2007). Booms and busts: The case of subprime mortgages. Paper presented at the synposium "Housing, Housing Finance, and Monetary Policy," organized by the Federal Reserve Bank of Kansas City, Jackson Hole, Wyoming, August 30-September 1, 2007; www.KansaCityFed.org.

International Monetary Fund (2008a). Global financial stability report: Containing systemic risks and restoring financial soundness, April 2008. Washington, DC. 
International Monetary Fund (2008b). Global financial stability report: Financial stress and deleveraging, macrofinancial implications and policy, October 2008. Washington, DC.

Kindleberger, Charles P. (1978 [2000]). Manias, panics, and crashes: A history of financial crises, $4^{\text {th }}$ edition, New York: Wiley.

Leach, James A. (2008). Fixing Fannie and Freddie: A ‘buy-in’ for taxpayers rather than 'bail-out' for shareholders, Harvard University, John F. Kennedy School of Government, Institute of Politics, July 16.

Minsky, Hyman (1977). A theory of systemic fragility. in E. J. Altman and A. W. Sametz (eds). Financial crises: Institutions and markets in a fragile environment. New York. Wiley, 138-52.

Minsky, Hyman (1982). Can “it” happen again? Essays on instability and finance. Armon, NY: M.E. Sharpe.

Mishkin, Frederic S. (1991). Asymmetric information and financial crises: A historical perspective. In R. Glenn Hubbard (ed.), Financial Markets and Financial Crises. Chicago: The University of Chicago Press.

Nakaso, Hiroshi (2001). The financial crisis in Japan during the 1990s: how the Bank of Japan responded and the lessons learnt. BIS Papers N. 6 (October).

Savona, Paolo and Aurelio Maccario (1999). On the relation between money and derivatives and its application to the international monetary market, Open Economies Review 9:S1 637-664.

Standard \& Poor's. S\&P/Case-Shiller Home Price Indices; http://www2.standardandpoors.com/portal/site/sp/en/us/page.topic/indices_csmahp/2,3,4,0,0, $\underline{0,0,0,0,0,0,0,0,0,0,0 . h t m l}$

Trzcinka , Charles (2009). F529 class notes, Indiana University, Department of Finance.

Wallison, Peter J. (2008). Fair value accounting: A critique, American Enterprise Institute for Public Policy Reseach, July; http://www.aei.org/publications/pubID.28389/pub_detail.asp

Wallison, Peter J. (2009). The true origins of this financial crisis, American Enterprise Institute for Public Policy Reseach, February; http://www.aei.org/publications/filter.all,pubID.29419/pub_detail.asp 


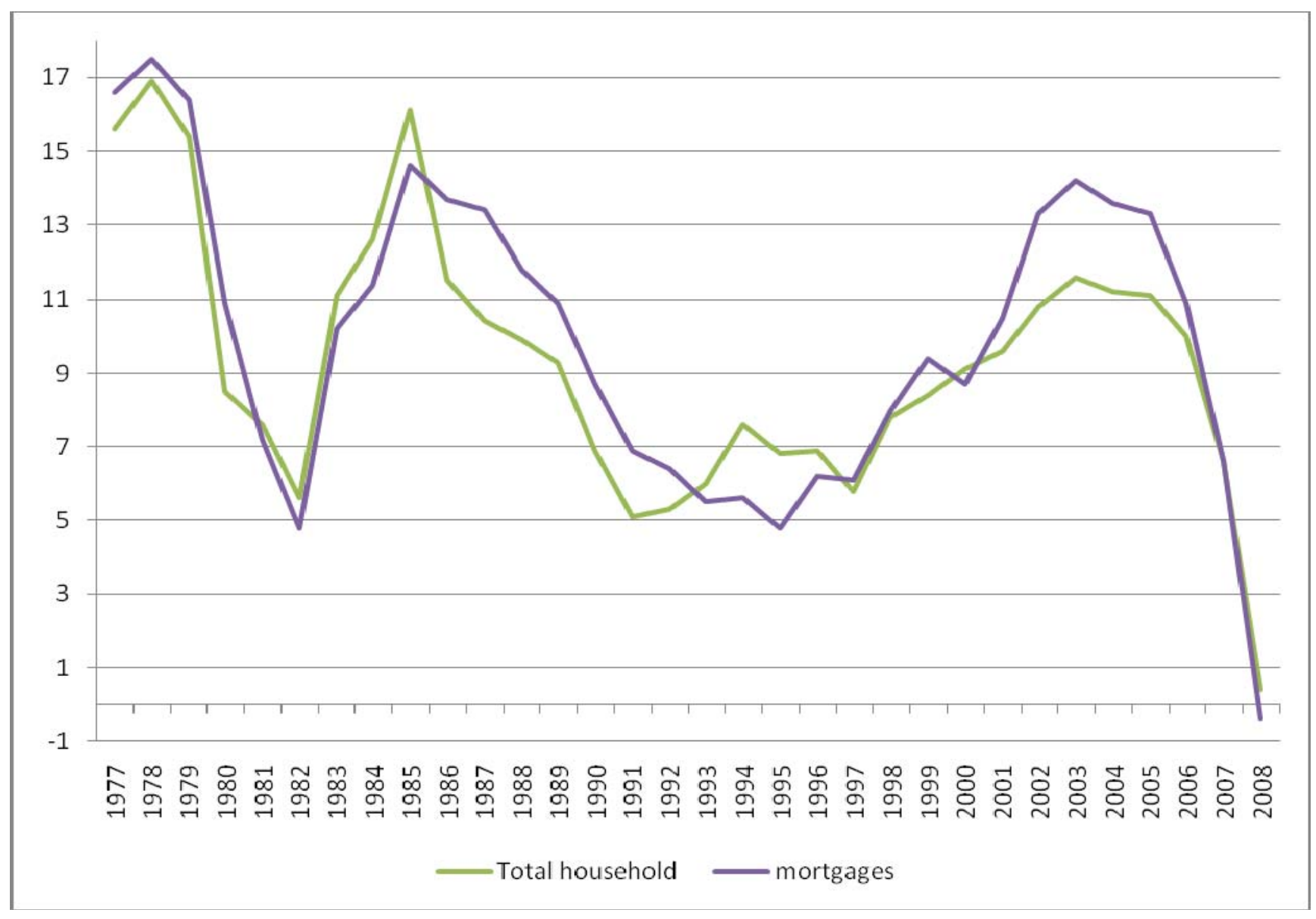

Figure 1: Annual growth of US households' debt and mortgages. Source: Board of Governores of the Federal Reserve System, Flow of Funds Accounts of the United States. 


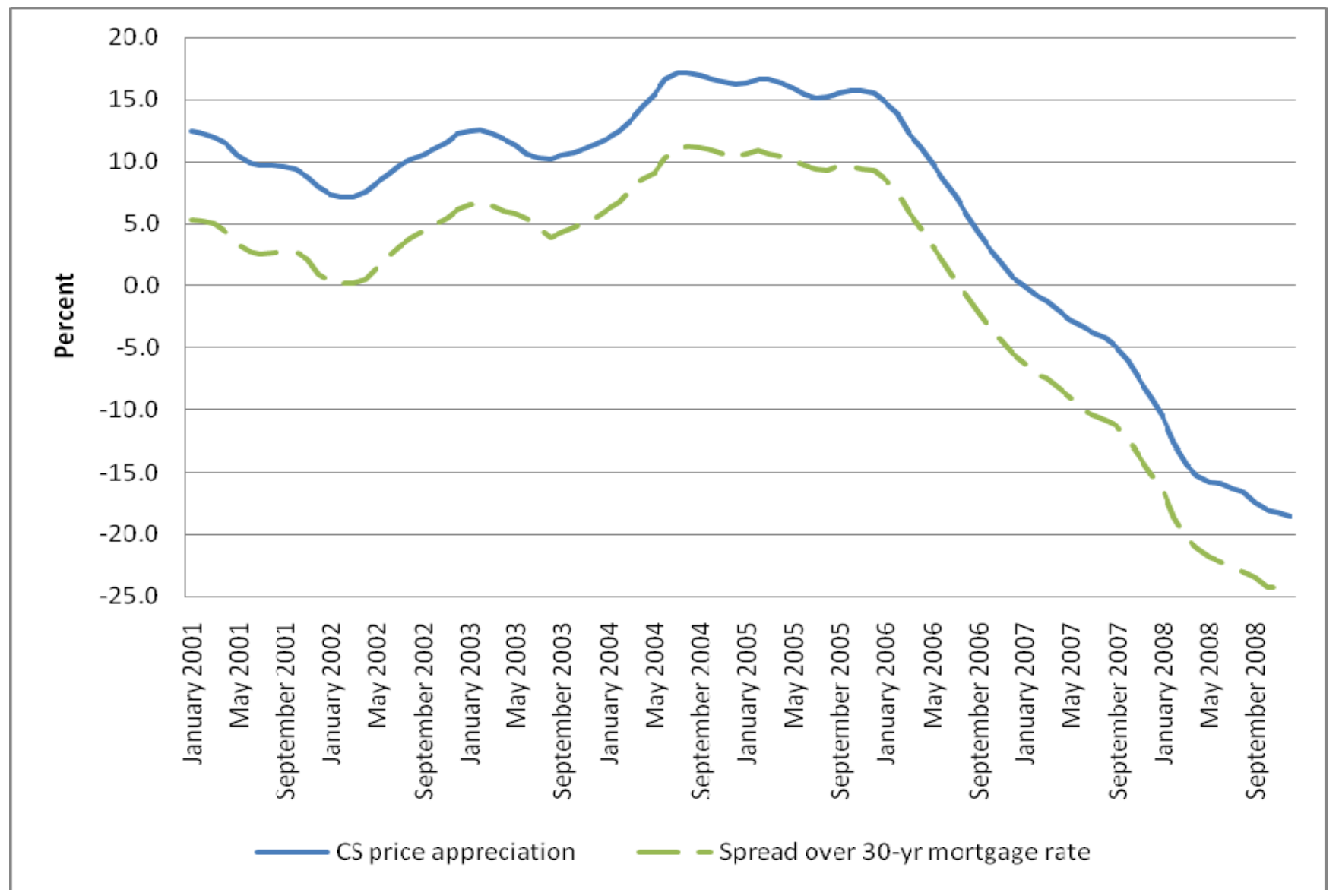

Figure 2: S\&P/Case-Shiller US home price appreciation and its spread over the 30-year conventional mortgage rate, 2001-2008. Source: Standard \& Poor’s, http://www2.standardandpoors.com/portal/site/sp/en/us/page.topic/indices_csmahp/2,3,4,0,0,0,0,0,0,0 , 0,0,0,0,0,0.html; and Board of Governors of the Federal Reserve System, 30-year conventional mortgage interest rate series. 


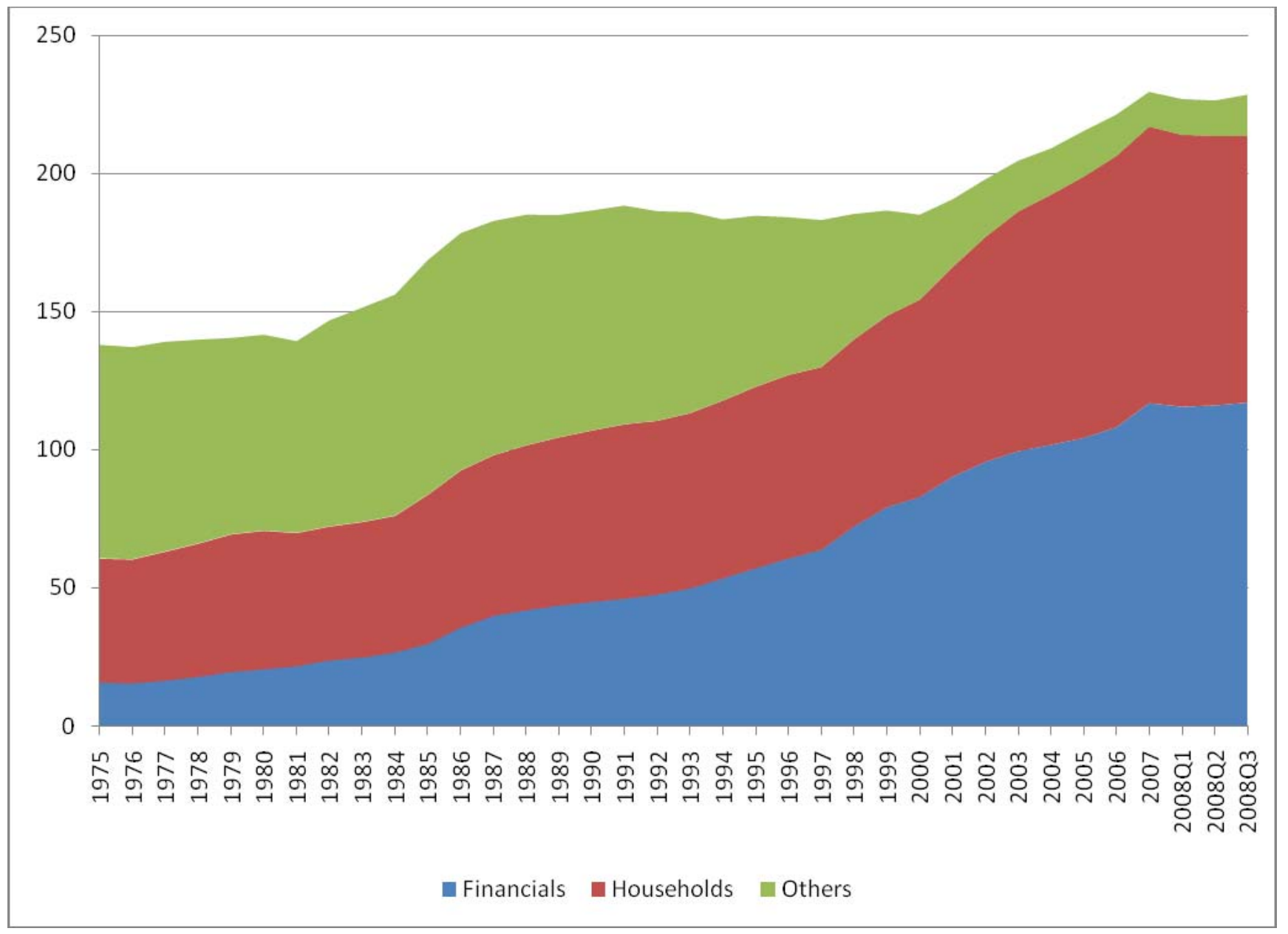

Figure 3: Debt levels of US sectors as a percent of US GDP, from 1975 to the third quarter of 2008. Source: Board of Governores of the Federal Reserve System, Flow of funds accounts of the United States. 


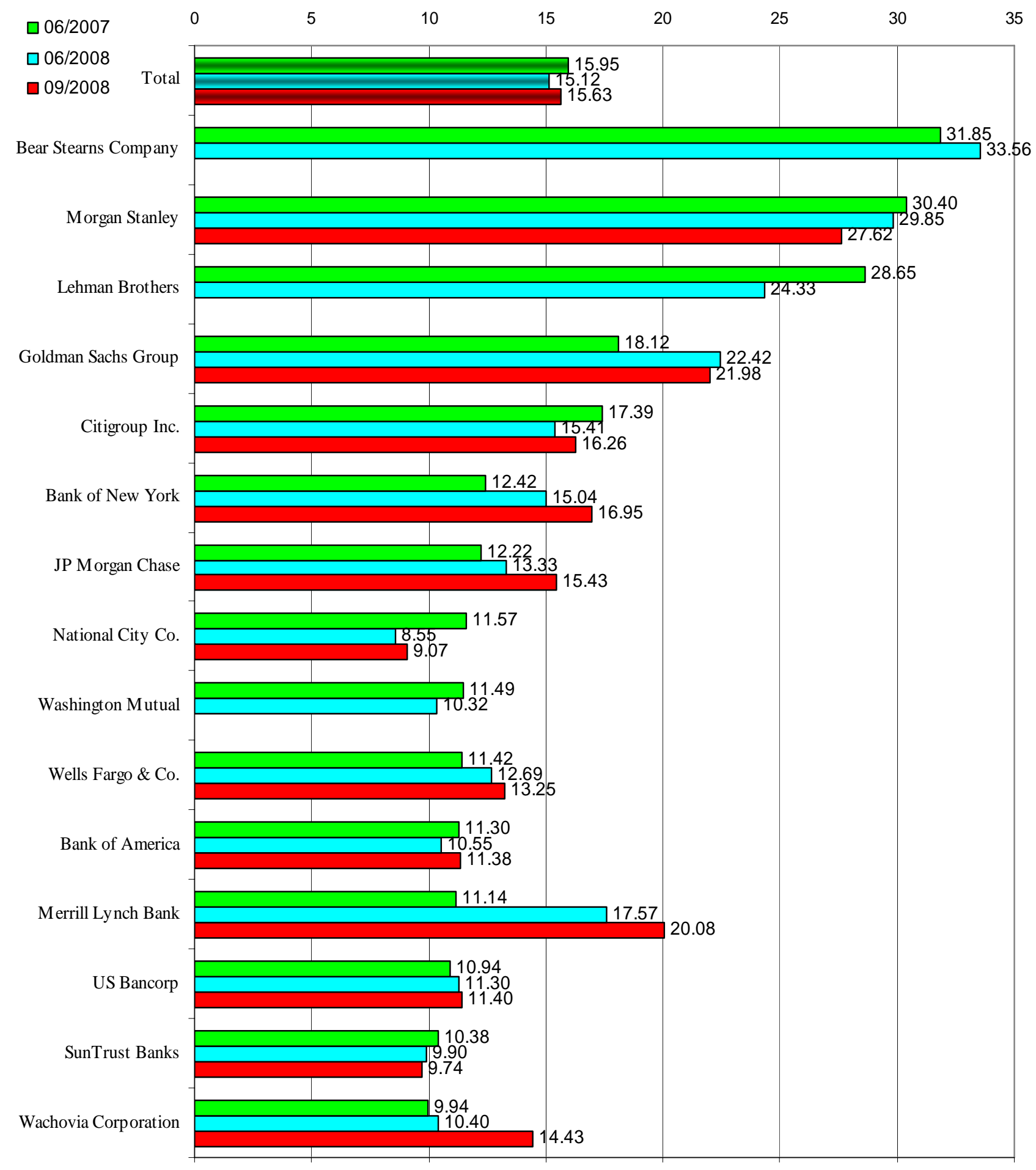

Note: Data for Bear Stearns Company was updated on March 2008. In the same month, Lehman Brothers' leverage rose to 31.65 .

Figure 4: Leverage (Ratio of total assets to equity) of selected US banks in June 2007, June 2008, and September 2008. Source: Bankscope. 


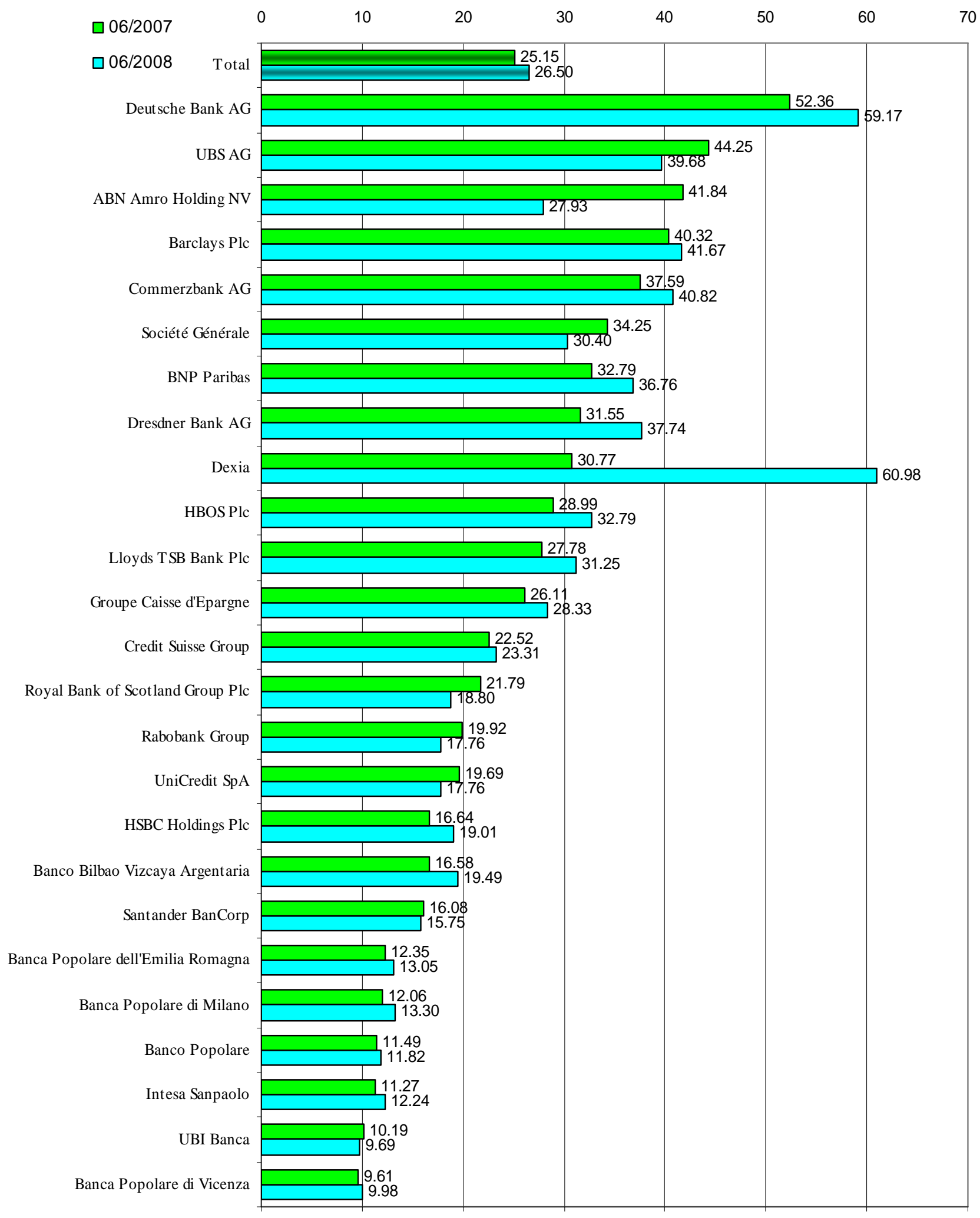

Figure 5: Leverage (Ratio of total assets to equity) of selected European and Italian banks in June 2007 and June 2008. Source: Bankscope. 


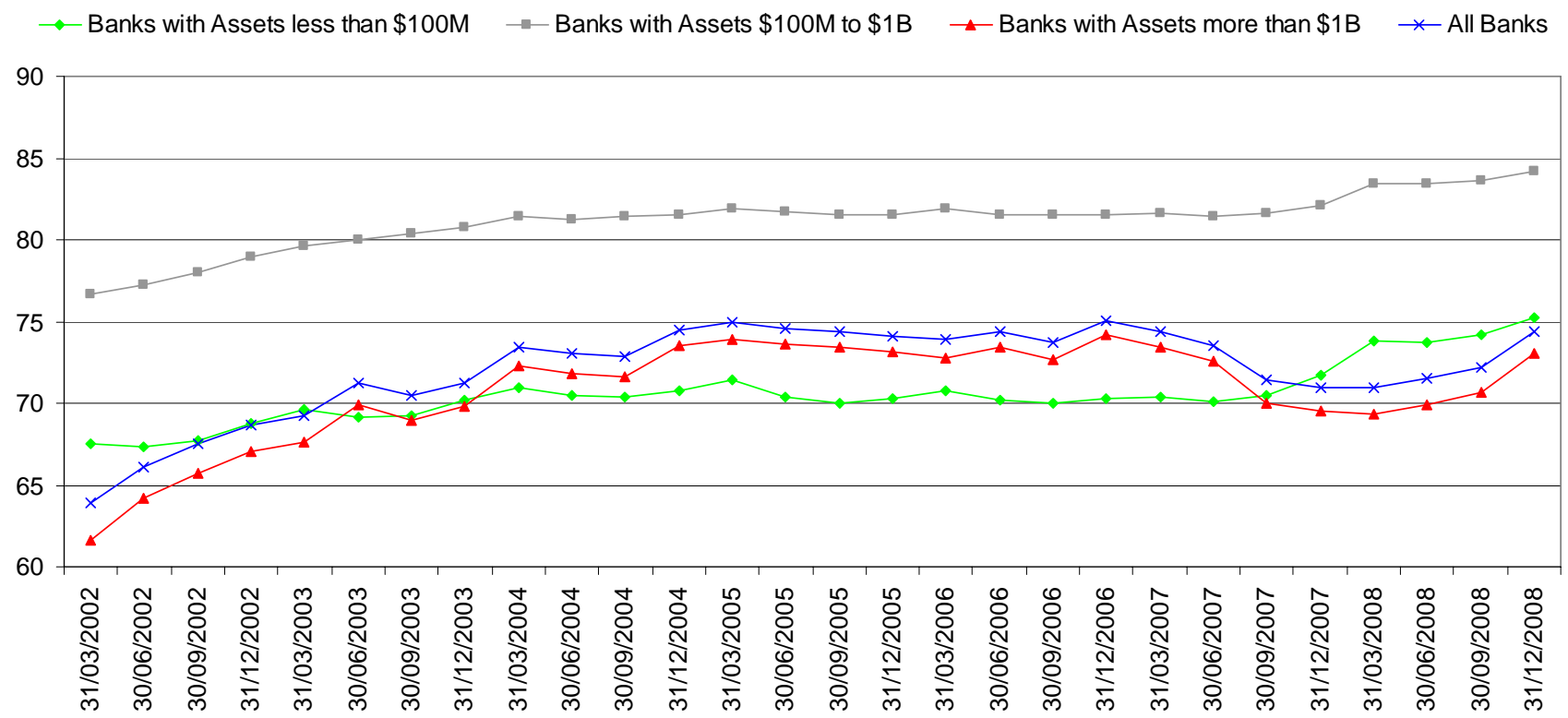

Figure 6: High-risk US commercial bank loans as a percent of total assets, for different bank sizes. Source: Federal Deposit Insurance Corporation, Statistics on banking; http://www2.fdic.gov/SDI/SOB/.

End 2002

End 2006

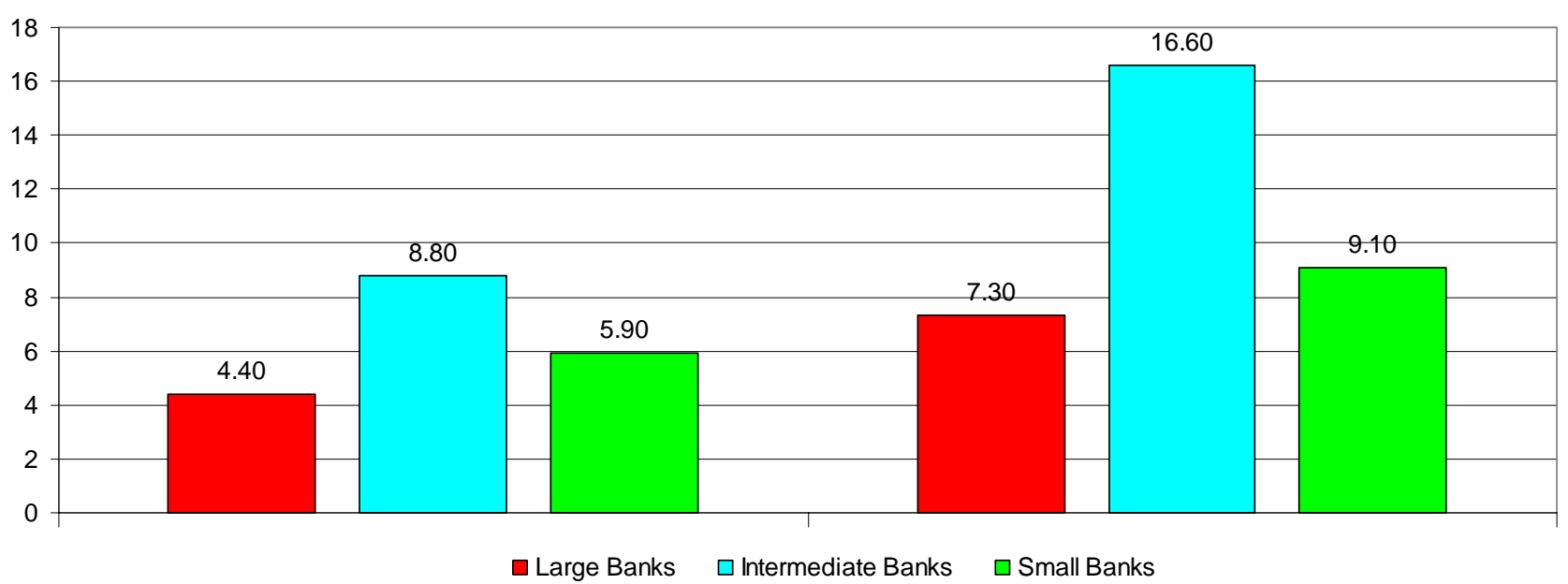

Figure 7: Construction and development loans by US banks, as a percent of net loans and leases, for different bank sizes, year end 2002 and 2006. Source: Federal Deposit Insurance Corporation, Statistics on banking; http://www2.fdic.gov/SDI/SOB/. 
- Banks with Assets less than \$100M - Banks with Assets \$100M to \$1B $\_$Banks with Assets more than \$1B $\rightarrow$ - All Banks

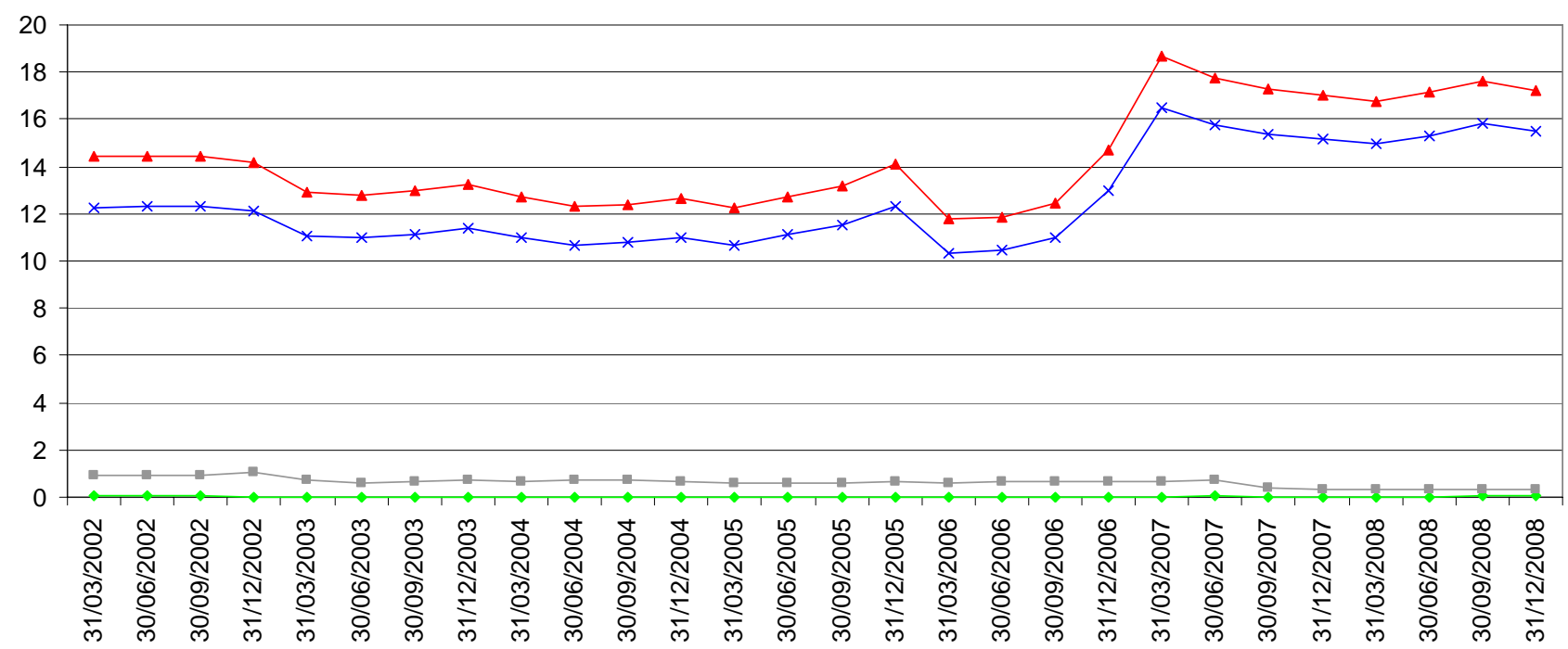

Figure 8: Value of US bank securitization activities as a percent of total assets, for different bank sizes. Source: Federal Deposit Insurance Corporation, Statistics on banking; http://www2.fdic.gov/SDI/SOB/

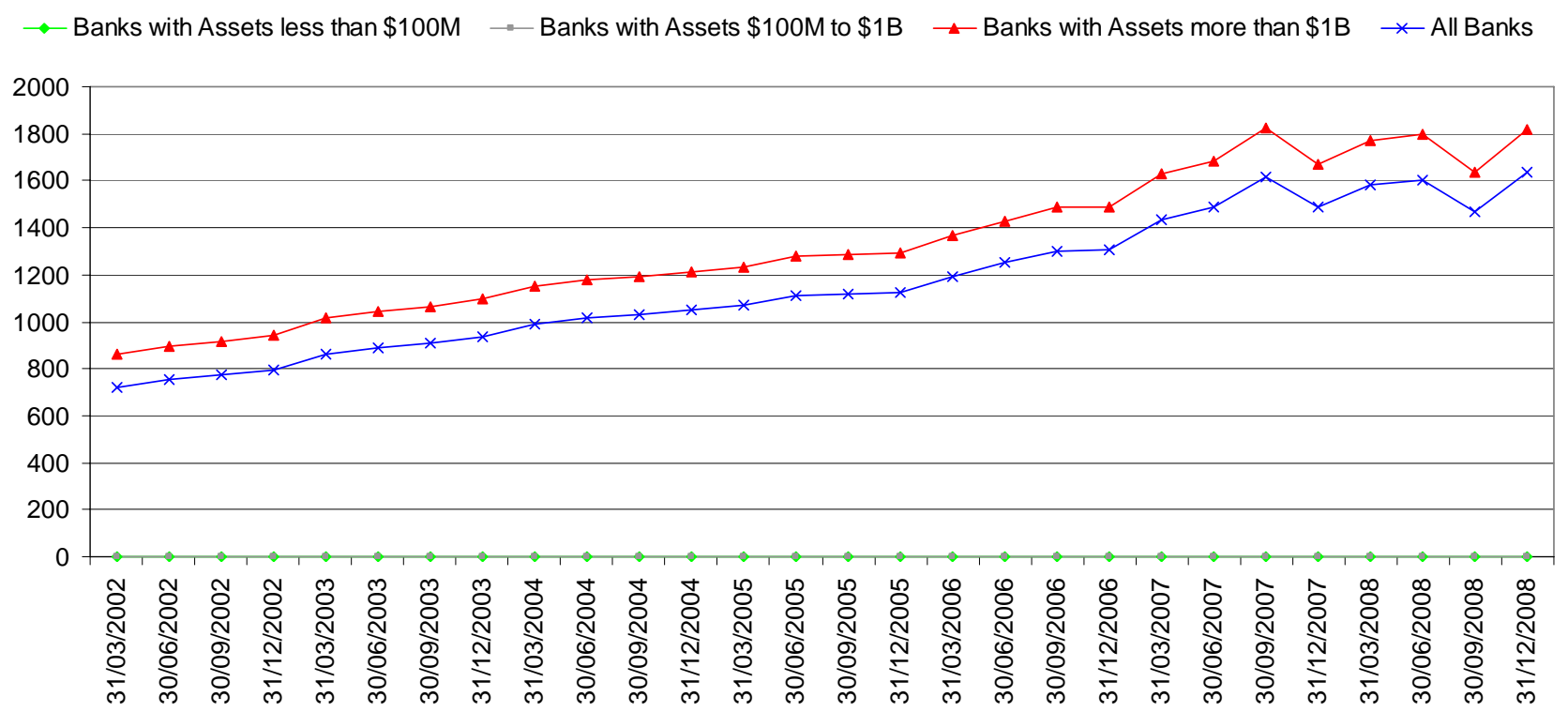

Figure 9: Value of US bank derivatives as a percent of total assets, for different bank sizes. Source: Federal Deposit Insurance Corporation, Statistics on banking; http://www2.fdic.gov/SDI/SOB/ 


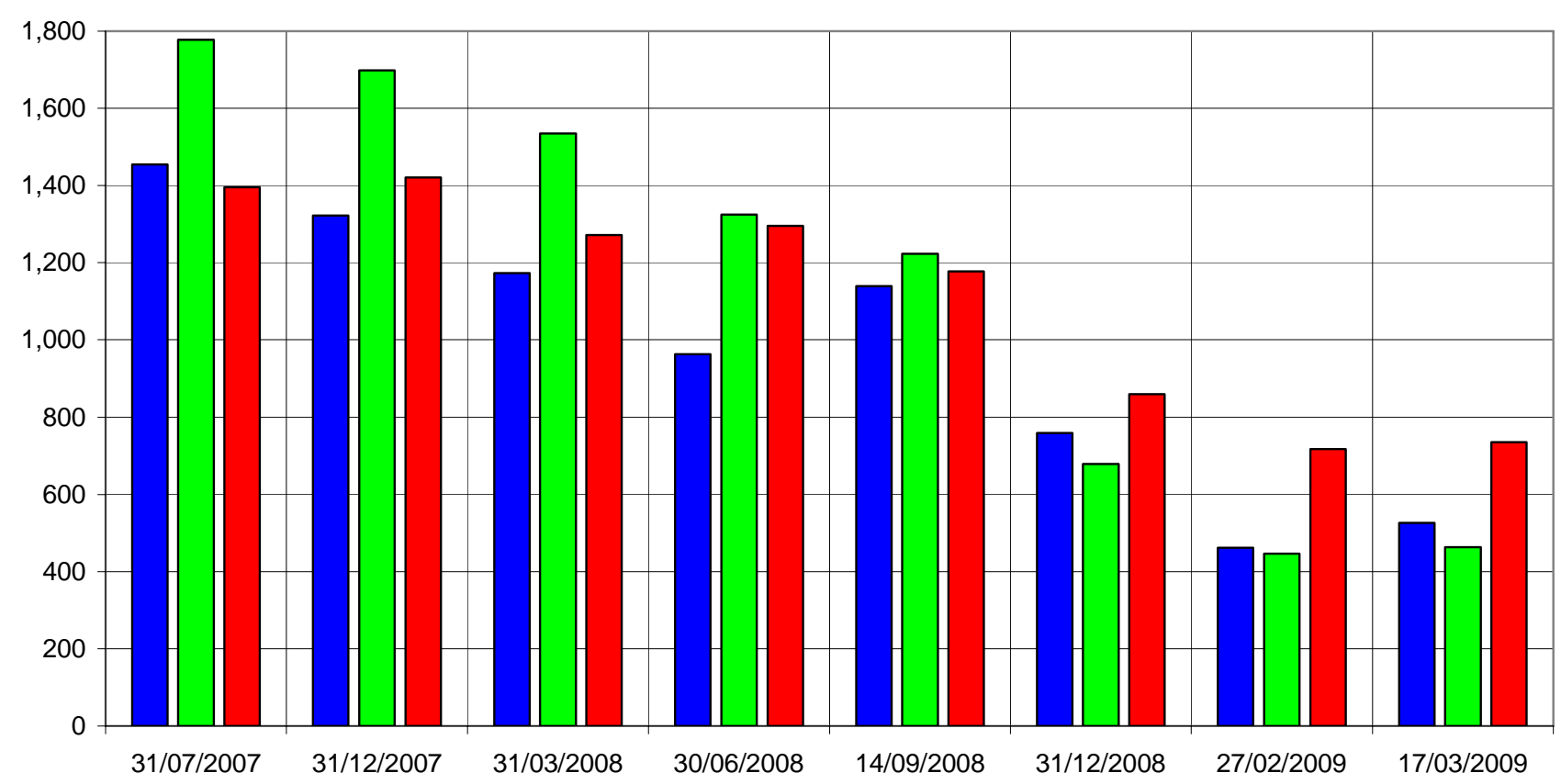

Figure 10: Market capitalization of a sample of US, European , and Pacific region banks from end of July, 2007 to March 17, 2008, in US\$ billion. Source: Bloomberg.

口USA $\square$ Europe $\square$ Pacific

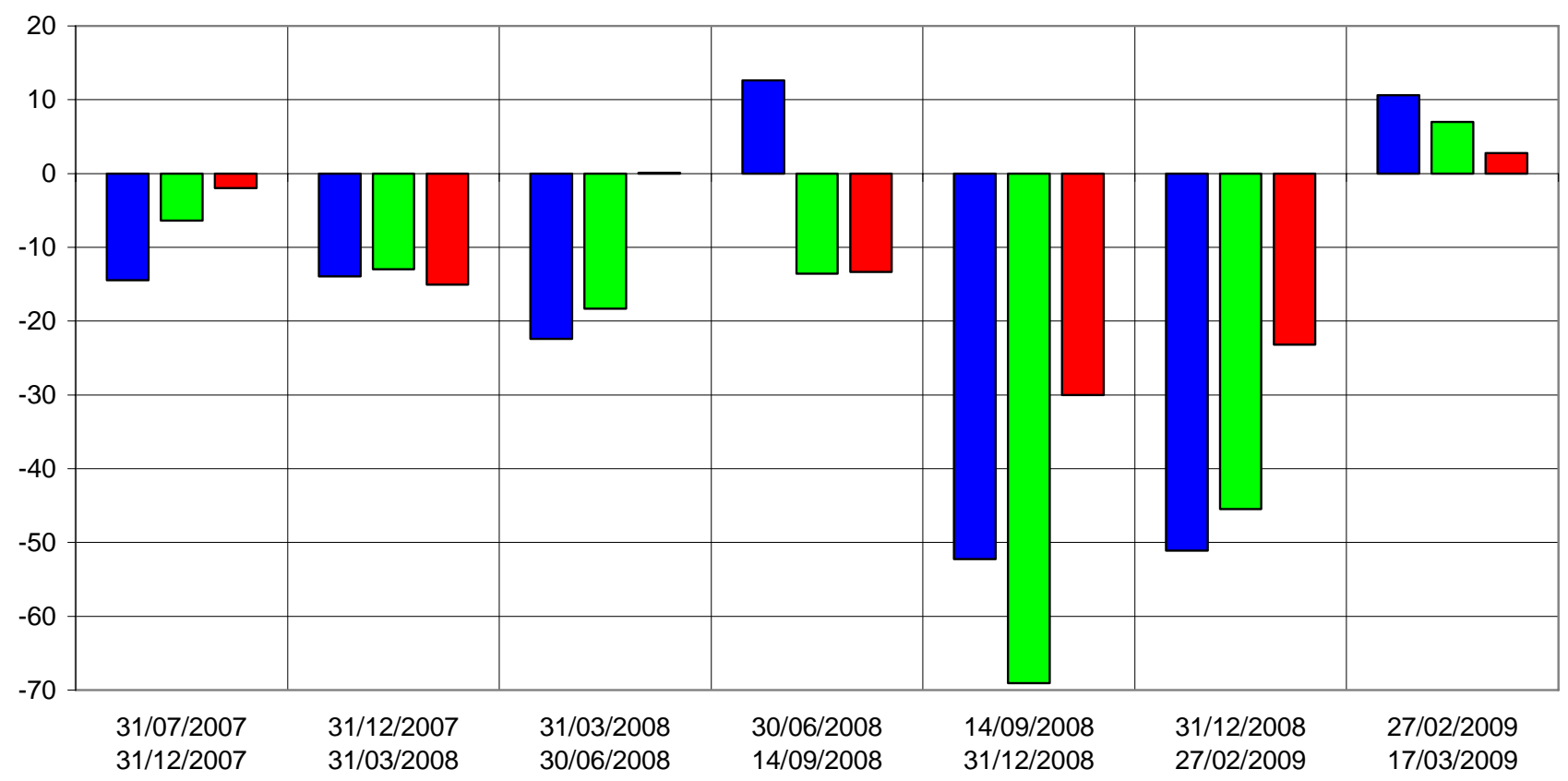

Figure 11: Holding-period dollar rates of return on a sample of US, European, and Pacific region banks from end of July, 2007 to March 17, 2008. Source: Bloomberg. 


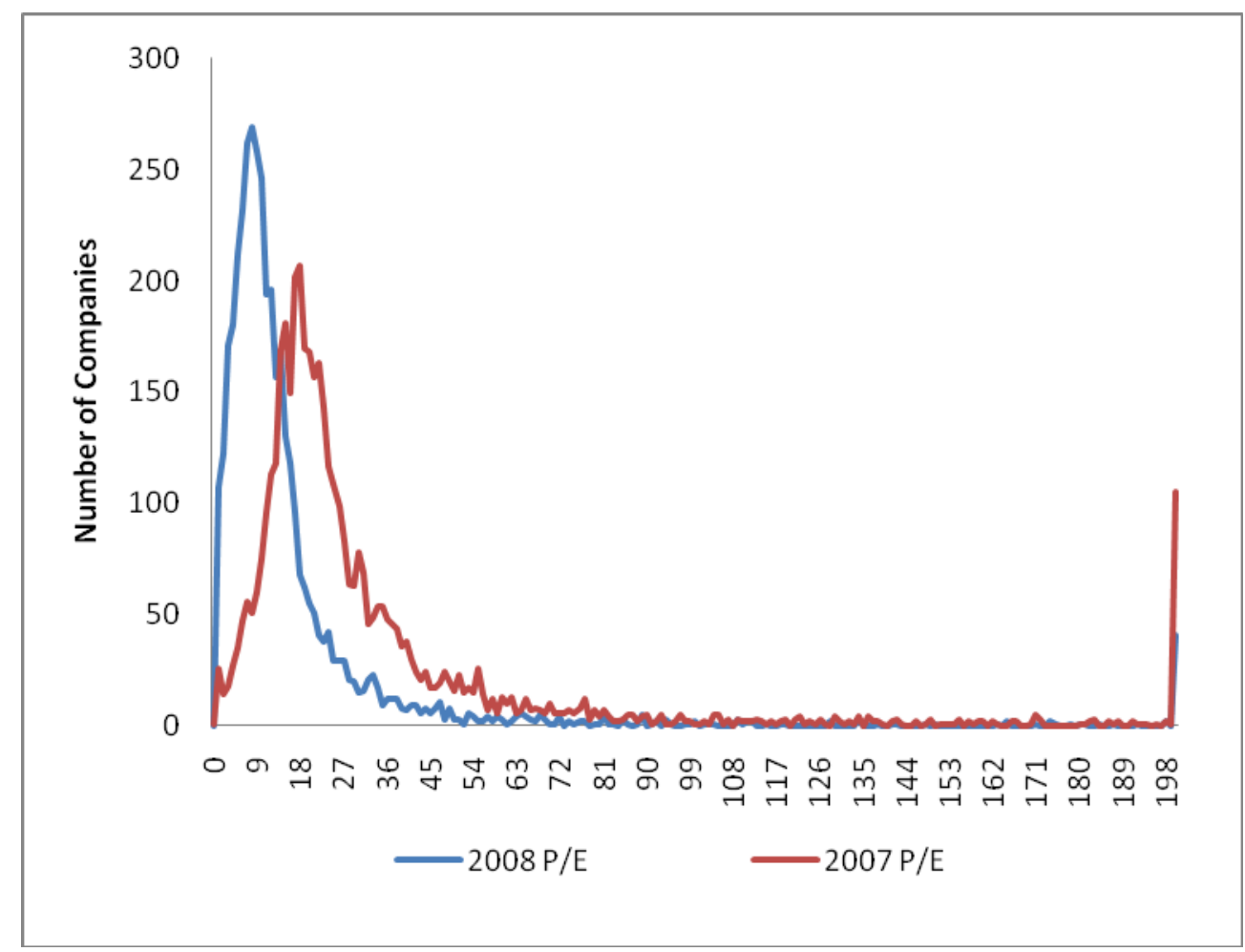

Figure 12. Shift in the price-earnings ratio of US stocks, 2007-2008. $2007 \mathrm{P} / \mathrm{E}$ and $2008 \mathrm{P} / \mathrm{E}$ observations refer to end of January 2008 and 2009, respectively. Source: F529 class notes by Professor Charles Trzcinka, Indiana University, Department of Finance. 
Table 1: US saving and investment, 2001-2008 (billions of dollars)

$\begin{array}{lrrrrrrrrc} & 2001 & 2002 & 2003 & 2004 & 2005 & 2006 & 2007 & 2008 & \text { Sum } \\ & 325 & 479 & 549 & 551 & 494 & 569 & 454 & 474 & \\ \text { Net private saving } & 52 & -282 & -406 & -369 & -262 & -155 & -219 & -580 & \\ \text { Net government saving } & 1281 & 1292 & 1331 & 1436 & 1612 & 1624 & 1720 & 1832 & \\ \text { Fixed capital consumption } & 1938 & 1926 & 2026 & 2261 & 2484 & 2647 & 2593 & 2492 & \\ \text { Gross domestic investment } & 1 & 1 & 3 & 2 & 4 & 4 & 2 & 3 & \\ \text { Net capital account } & -90 & -21 & 47 & 19 & -71 & -163 & -81 & 94 & \\ \text { Statistical discrepancy } & -371 & -459 & -508 & -626 & -715 & -776 & -721 & -675 & -3455 \\ \text { Net foreign lending or borrowing } & & & & & & & & \end{array}$

Source: Board of Governores of the Federal Reserve System, Flow of funds accounts of the United States.

Table 2: Rates of returns local currency and in dollars on selected US, European and Pacific region banks, in percent, end of July 2007 to March 17, 2009.

\begin{tabular}{|c|c|c|c|c|c|c|c|c|c|c|}
\hline \multirow[t]{2}{*}{ Area } & \multirow[t]{2}{*}{ Country } & \multicolumn{3}{|c|}{$31 / 07 / 2007$ 14/09/2008 } & \multicolumn{3}{|c|}{ 31/07/2007 27/02/2009 } & \multicolumn{3}{|c|}{ 31/07/2007 17/03/2009 } \\
\hline & & LCU & EXC & USD & LCU & EXC & USD & LCU & EXC & USD \\
\hline \multirow[t]{14}{*}{ Europe } & AT & -42.29 & 3.31 & -40.38 & -199.55 & -7.96 & -191.63 & -171.86 & -6.17 & -167.42 \\
\hline & $\mathrm{BE}$ & -54.70 & 3.31 & -53.20 & -248.50 & -7.96 & -236.68 & -232.16 & -6.17 & -224.01 \\
\hline & DE & -62.64 & 3.31 & -61.40 & -268.89 & -7.96 & -255.44 & -272.16 & -6.17 & -261.54 \\
\hline & ES & -43.13 & 3.31 & -41.25 & -88.22 & -7.96 & -89.16 & -86.45 & -6.17 & -87.29 \\
\hline & FR & -64.80 & 3.31 & -63.63 & -155.04 & -7.96 & -150.66 & -144.06 & -6.17 & -141.34 \\
\hline & GR & -42.60 & 3.31 & -40.71 & -153.46 & -7.96 & -149.20 & -150.57 & -6.17 & -147.45 \\
\hline & IE & -88.06 & 3.31 & -87.66 & -391.20 & -7.96 & -368.02 & -355.35 & -6.17 & -339.61 \\
\hline & IT & -42.66 & 3.31 & -40.76 & -113.48 & -7.96 & -112.41 & -119.70 & -6.17 & -118.48 \\
\hline & $\mathrm{PT}$ & -92.67 & 3.31 & -92.42 & -149.26 & -7.96 & -145.34 & -143.55 & -6.17 & -140.87 \\
\hline & $\mathrm{CH}$ & 13.55 & 5.87 & 20.21 & 14.86 & 2.95 & 18.25 & 15.41 & 1.18 & 16.78 \\
\hline & DK & -49.98 & 3.10 & -48.43 & -155.03 & -8.08 & -150.59 & -143.84 & -6.39 & -141.04 \\
\hline & NO & -30.46 & 1.44 & -29.45 & -110.83 & -19.35 & -108.73 & -102.07 & -16.44 & -101.73 \\
\hline & SE & -45.75 & 0.00 & -45.75 & -140.47 & -29.55 & -128.51 & -132.69 & -25.14 & -124.47 \\
\hline & UK & -54.14 & -12.92 & -60.06 & -216.15 & -35.52 & -174.90 & -208.98 & -37.67 & -167.93 \\
\hline \multicolumn{2}{|c|}{ Europe Total } & -50.92 & 1.05 & -50.32 & -158.90 & -13.11 & -149.30 & -153.44 & -11.65 & -145.25 \\
\hline \multirow[t]{3}{*}{ Pacific } & HK & -12.05 & 0.39 & -11.70 & -67.18 & 0.86 & -66.90 & -70.18 & 0.93 & -69.90 \\
\hline & JP & -45.15 & 10.18 & -39.57 & -98.84 & 19.42 & -98.62 & -95.11 & 19.42 & -94.16 \\
\hline & $\mathrm{AU}$ & -30.34 & -5.06 & -33.87 & -73.46 & -29.18 & -81.21 & -67.52 & -26.76 & -76.21 \\
\hline \multicolumn{2}{|c|}{ Pacific Total } & -31.55 & 3.65 & -29.68 & -83.24 & 2.49 & -84.84 & -81.07 & 3.07 & -82.55 \\
\hline USA & US & -38.13 & 0.00 & -38.13 & -142.39 & 0.00 & -142.39 & -132.03 & 0.00 & -132.03 \\
\hline \multicolumn{2}{|l|}{ USA Total } & -38.13 & 0.00 & -38.13 & -142.39 & 0.00 & -142.39 & -132.03 & 0.00 & -132.03 \\
\hline
\end{tabular}

Legend: LCU = rate of return in local-currency units, EXC = depreciation/appreciation of the US dollar relative to the local currency, USD = rate of return in dollars, $\mathrm{AT}=$ Austria, $\mathrm{BE}=$ Belgium; $\mathrm{CH}=$ Switzerland; $\mathrm{DE}=\mathrm{Germany}$; DK=Danmark; ES=Spain; FR=France; GR=Greece; IE=Eire; IT=Italy; NO=Norway; PT=Portugal; SE=Sweden; UK=United Kingdom; AU=Australia; HK=Hong-Kong; JP=Japan; US=United States. Source: Bloomberg. 
Appendix: List of banks included in market capitalization

\begin{tabular}{|c|c|c|c|}
\hline Area & Country & Bank Nr. & Bank Name \\
\hline \multirow{14}{*}{ Europe } & $\mathrm{AT}$ & 2 & ERSTE GROUP BANK AG, RAIFFEISEN INTL BANK HOLDING \\
\hline & $\mathrm{BE}$ & 2 & DEXIA SA, KBC GROEP NV \\
\hline & $\mathrm{CH}$ & 1 & VALIANT HOLDING AG-REG \\
\hline & $\mathrm{DE}$ & 3 & $\begin{array}{lllllll}\text { COMMERZBANK } & \text { AG, } \\
\text { HOLDING } & \text { DEUTSCHE } & \text { POSTBANK } & \text { AG, HYPO } & \text { REAL } & \text { ESTATE } \\
& & & & & \end{array}$ \\
\hline & DK & 3 & DANSKE BANK A/S, JYSKE BANK-REG, SYDBANK A/S \\
\hline & ES & 6 & $\begin{array}{l}\text { BANCO BILBAO VIZCAYA ARGENTA, BANCO DE VALENCIA SA, BANCO } \\
\text { POPULAR ESPANOL, BANCO SANTANDER SA, BANKINTER SA }\end{array}$ \\
\hline & FR & 4 & BNP PARIBAS, CREDIT AGRICOLE SA, NATIXIS, SOCIETE GENERALE \\
\hline & GR & 5 & $\begin{array}{l}\text { ALPHA BANK A.E., BANK OF GREECE, EFG EUROBANK ERGASIAS, NATIONAL } \\
\text { BANK OF GREECE, PIRAEUS BANK S.A. }\end{array}$ \\
\hline & IE & 1 & ALLIED IRISH BANKS PLC \\
\hline & IT & 8 & $\begin{array}{l}\text { BANCA CARIGE SPA, BANCA MONTE DEI PASCHI SIENA, BANCA POPOLARE DI } \\
\text { MILANO, BANCO POPOLARE SCARL, INTESA SANPAOLO, PICCOLO CREDITO } \\
\text { VALTELLINESE, UBI BANCA SCPA, UNICREDIT SPA }\end{array}$ \\
\hline & NO & 1 & DNB NOR ASA \\
\hline & PT & 3 & BANCO BPI SA, BANCO COMERCIAL PORTUGUES, BANCO ESPIRITO SANTO \\
\hline & SE & 4 & $\begin{array}{l}\text { NORDEA BANK AB, SKANDINAVISKA ENSKILDA, SVENSKA HANDELSBANKEN } \\
\text { SHS, SWEDBANK AB }\end{array}$ \\
\hline & UK & 6 & $\begin{array}{l}\text { BANK OF IRELAND, BARCLAYS PLC, HSBC HOLDINGS PLC, LLOYDS BANKING } \\
\text { GROUP PLC, ROYAL BANK OF SCOTLAND, STANDARD CHARTERED PLC }\end{array}$ \\
\hline \multirow{3}{*}{ Pacific } & $\mathrm{AU}$ & 6 & $\begin{array}{l}\text { AUST AND NZ BANKING GROUP, BANK OF QUEENSLAND LTD, BENDIGO AND } \\
\text { ADELAIDE BANK, COMMONWEALTH BANK OF AUSTRALIA, NATIONAL } \\
\text { AUSTRALIA BANK LTD, WESTPAC BANKING CORP }\end{array}$ \\
\hline & HK & 8 & $\begin{array}{l}\text { BANK OF CHINA LTD, BANK OF COMMUNICATIONS CO, BANK OF EAST ASIA, } \\
\text { BOC HONG KONG HOLDINGS LTD, CHINA CONSTRUCTION BANK, HANG SENG } \\
\text { BANK LTD, HSBC HOLDINGS PLC, IND \& COMM BANK OF CHINA }\end{array}$ \\
\hline & JP & 12 & $\begin{array}{l}\text { BANK OF YOKOHAMA LTD, CHIBA BANK LTD, CHUO MITSUI TRUST } \\
\text { HOLDINGS, FUKUOKA FINANCIAL GROUP INC, MITSUBISHI UFJ FINANCIAL } \\
\text { GROUP, MIZUHO FINANCIAL GROUP INC, MIZUHO TRUST \& BANKING CO, } \\
\text { RESONA HOLDINGS INC, SHINSEI BANK LTD, SHIZUOKA BANK LTD, } \\
\text { SUMITOMO MITSUI FINANCIAL GROUP, SUMITOMO TRUST \& BANKING CO }\end{array}$ \\
\hline USA & US & 42 & $\begin{array}{l}\text { AMERICAN CAPITAL LTD, AMERICAN EXPRESS CO, AMERIPRISE FINANCIAL } \\
\text { INC, BANK OF AMERICA CORP, BANK OF NEW YORK MELLON CORP, BB\&T } \\
\text { CORP, CAPITAL ONE FINANCIAL CORP, CIT GROUP INC, CITIGROUP INC, } \\
\text { COMERICA INC, E*TRADE FINANCIAL CORP, FEDERATED INVESTORS INC, } \\
\text { FIFTH THIRD BANCORP, FIRST HORIZON NATIONAL CORP, FRANKLIN } \\
\text { RESOURCES INC, GOLDMAN SACHS GROUP INC, HUDSON CITY BANCORP INC, } \\
\text { HUNTINGTON BANCSHARES INC, INTERCONTINENTALEXCHANGE INC, JANUS } \\
\text { CAPITAL GROUP INC, JPMORGAN CHASE \& CO, KEYCORP, LEGG MASON INC, } \\
\text { LEUCADIA NATIONAL CORP, M \& T BANK CORP, MARSHALL \& ILSLEY COR, } \\
\text { MOODY'S CORP, MORGAN STANLEY, NASDAQ OMX GROUP, NORTHERN } \\
\text { TRUST CORP, NYSE EURONEXT, PEOPLE'S UNITED FINANCIAL, PNC } \\
\text { FINANCIAL SERVICES GROUP, REGIONS FINANCIAL CORP, SCHWAB } \\
\text { (CHARLES) CORP, SLM CORP, STATE STREET CORP, SUNTRUST BANKS INC, T } \\
\text { ROWE PRICE GROUP INC, US BANCORP, WELLS FARGO \& CO, ZIONS } \\
\text { BANCORPORATION }\end{array}$ \\
\hline
\end{tabular}

Legend: AT=Austria, BE=Belgium; $\mathrm{CH}=$ Switzerland; $\mathrm{DE}=$ Germany; DK=Denmark; ES=Spain; FR=France; GR=Greece; IE=Eire; IT=Italy; NO=Norway; PT=Portugal; SE=Sweden; UK=United Kingdom; AU=Australia; HK=Hong-Kong; $\mathrm{JP}=$ Japan; US=United States. Source: Bloomberg. 